\title{
Professional development initiatives as a lever for inclusive education: a multiple case study using qualitative comparative analysis (QCA)
}

\author{
Aster Van Mieghem ${ }^{\mathrm{a}, \mathrm{b}, 1}$, Karine Verschueren ${ }^{\mathrm{b}}$, Elke Struyf $^{\mathrm{c}}$ \\ ${ }^{a}$ Faculty of Social Sciences, Department of Training and Educational Sciences, University of Antwerp, Sint-Jacobsstraat 2 , \\ 2000 Antwerp, Belgium; \\ ${ }^{b}$ Faculty of Psychology and Educational Sciences, School Psychology and Child and Adolescent Development, KU Leuven, \\ Tiensestraat 102, 3000 Leuven, Belgium; \\ ${ }^{c}$ Faculty of Social Sciences, Department of Training and Educational Sciences, University of Antwerp, Venusstraat 35, 2000 \\ Antwerp.
}

\begin{abstract}
The move to include students with special educational needs (SEN) in mainstream education is one of the priorities of educational reform agendas in many countries. Also in Flanders (Belgium) the government's aim is to implement a more inclusive school system, but this faces some resistance from practitioners. This study examines the way in which professional development initiatives (PDIs) supporting inclusive education can reduce this resistance. PDI's are defined by the nine key features of Merchie et al. (2018), which are subdivided in four core (referring to the content): (1) content focus, (2) pedagogical knowledge, (3) coherent and evidence-based, and (4) ownership; and five structural features (referring to the design of a PDI): (1) duration, (2) collective or collaborative participation, (3) school- or site based, (4) active learning, and (5) trainer quality. The results indicate that school team members' positive experiences with students with special educational needs (SEN) have more impact on the willingness to include them than the core or structural features of PDIs. Furthermore, indications were found that PDIs focussing on a specific SEN can create more willingness to include these students.
\end{abstract}

\section{Key words}

Professional development initiatives, inclusive education, special educational needs, qualitative comparative analysis (QCA)

${ }^{1}$ Corresponding author. Department of Training and Educational Sciences, Faculty of Social Sciences, University of Antwerp, Sint-Jacobsstraat 2, 2000 Antwerp, Belgium, Aster.VanMieghem@UAntwerpen.be 


\section{Introduction}

Inclusive education (IE) has already long been the subject on the worldwide reform agenda (e.g., United Nations, 2006). Also Belgium ratified the UN Convention on the Rights of Persons with Disabilities in 2009, which entails that an IE should be realized at all levels (article 24). Consequently, recent legislation (implemented in 2015-2016) in Flanders, the Dutch speaking part of Belgium, intends to diminish the current segregated school system in favour of IE (Flemish Ministry of Education and Training, 2014). In line with this recent legislation reform, IE is defined as the commitment to include more students with special educational needs (SEN) in mainstream education (Ainscow, Booth, \& Dyson, 2006) by improving and adapting classroom practices to the individual needs of the learner (de Boer, Pijl, \& Minnaert, 2011).

A number of national guidelines supporting the inclusion of SEN-students in regular schools have been defined such as the right of SEN-students to register in a mainstream school unless the necessary adaptations are assessed as unreasonable or disproportional by the school. Schools in Flanders have a lot of autonomy about how they organize themselves. Consequently, they implement this new legislation in line with the school's context (e.g., size of the school, school network, situated in a rural or urban region, competences within the school team, integrated guidance school policy), which results in differences in implementation (School inspectorate, 2018). In Flanders, students in primary and secondary education can enrol in grant-aided free schools, grant-aided official schools, or community schools. Each group of schools is called a school network.

Because this legislation is only recently adopted, the willingness to include SEN-students within the school is the focus of this study. In line with the theory of planned behaviour of Ajzen (1991), willingness can be seen as the intention to perform a given behaviour. The stronger the intention, or in this study the willingness of school team members to include SEN-students, the more likely they will translate this intention into behavior (Ajzen, 1991).

Although the evolution towards IE is an international global trend, it must be realized in the local context and within the existing educational system (Vansteenkiste, Swart, Van Avermaet, \& Struyf, In press). In Flanders, practitioners find it challenging to implement this new legislation and thus tend to show resistance (Children's Rights Commissioner, 2016). After all, implementing IE requires school team members to adjust their practices and adopt new tasks that come along with instructing more SEN-students (Pijl \& Frissen, 2009). 
Research has indicated the importance of professionalization in establishing IE in a successful way (e.g., Avramidis \& Norwich, 2002; Van Mieghem, Verschueren, Petry, \& Struyf, 2020). Therefore, we hypothesize that professional development initiatives (PDIs) in favour of IE can reduce this resistance and can have a positive impact on the willingness of school team members to include SEN-students in their schools. In line with the implementation of a more inclusive school system in Flanders, professional development initiatives to support the realisation of IE were subsidised by the Flemish government. These initiatives all had the same goal; to strengthen school team members in the realisation of a more inclusive school. All initiatives were also set up by an external organisation such as a university college, a pedagogical guidance service or seconded teachers from special education schools. These external organisations were free to organise their initiative. As a result, the initiatives differed from each other in terms of duration, intensity, location, content, and so on (Struyf, Verschueren, Petry, Van Mieghem, 2018).

With regard to the effect of PDIs on teacher learning and school practice, Borko (2004) and Merchie, Tuytens, Devos, and Vanderlinde (2018) give an overview of relevant research. Based on this research, Merchie et al. (2018) developed a generic extended evaluative framework for mapping the effects of PDIs including six components (see Appendix), of which the 'features of the intervention' are considered as a fundamental base for developing a successful PDI. Therefore, this study aims to test in what way these nine key features of PDIs are associated to the willingness of school team members to include SEN-students (see Figure 1).

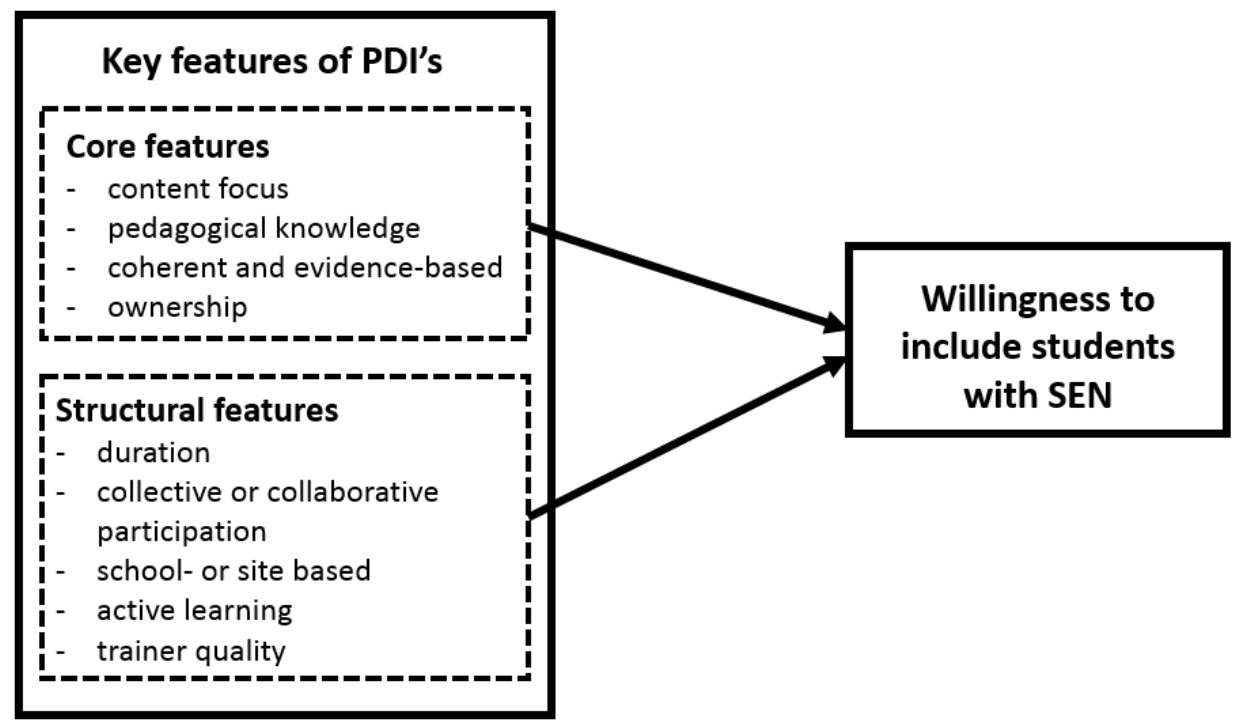

Figure 1: Focus of the study, based on the extended evaluative framework for mapping the effects of PDIs of Merchie et al. (2018) 


\subsection{Key features of PDIs}

The nine key features of Merchie et al. (2018) are subdivided in four core (referring to the content) and five structural features (referring to the design of a PDI). The four core features are: (1) content focus, (2) pedagogical knowledge, (3) coherent and evidence-based, and (4) ownership. The five structural features are: (1) duration, (2) collective or collaborative participation, (3) school- or site based, (4) active learning, and (5) trainer quality. These key features are derived from a systematic literature search that aimed to identify features that 'are repeatedly proven to be effective and are consistently noted in research' (p.148).

To gain more insight into the key features of successful PDIs in general according to Merchie et al. (2018), all core and structural features will be discussed and linked to IE.

\section{Core features}

The first core feature, 'content focus', concentrates on whether the PDI focusses on student learning and teaching (Merchie et al., 2018). The aim of IE is to teach SEN-students in mainstream schools (Ainscow, Booth, \& Dyson, 2006). Therefore, it is recommended that the PDI focusses on the learning of one or more SEN-students. The second core feature, 'pedagogical knowledge', refers to the knowledge and skills of teachers to teach the content that is of focus in the PDI (Merchie et al., 2018). By increasing the pedagogical knowledge of teachers to teach specific SEN-students, the aim is to reduce barriers for these students to learn and participate within the school, to eventually benefit students more widely (Booth \& Ainscow, 2002). The third core feature, 'coherent and evidence-based', advocates that the PDI is in line with the school team's goals, standards, current reforms, and that the approach in general is evidence-informed (Merchie et al, 2018). As a consequence of the new IE legislation, more SEN-students will be enrolled within mainstream schools. Depending on specific needs of SEN-students that register or are already enrolled and the existing agreements and procedures, school team members will experience different needs. Therefore, priorities for developing a more inclusive school should be identified within the school team (Booth \& Ainscow, 2002) and the PDI must be designed in a flexible way to meet these needs. The fourth core feature, 'ownership', demands that school team members can exercise ownership of the PDIs content and process (Merchie et al., 2018). As acknowledged by Booth and Ainscow (2002) school improvements need to be owned by staff, governors, parents/carers and students in order to be sustained (p.13). Ownership of the content and process of the PDI by individual school team members can only be obtained if the PDI is flexibly designed and meets the needs of individual school team members. 


\section{Structural features}

The first structural feature is the 'duration' of the PDI. According to Merchie and colleagues (2018) successful PDIs have an extended and intensive programme. Research of Desimone (2009) advises PDIs that are spread over a semester and exist out of 20 hours of contact time or more. In order to be able to answer to a specific need of a school team, related to teaching SEN-students, it is recommended that the necessary time is provided to investigate this need and cope with it in an appropriate way. Furthermore, research indicates that teachers benefit from follow-up sessions with regard to implementing IE (Van Mieghem et al., 2020). The second structural feature, 'collective or collaborative participation', advocates that the PDI should be based on collaboration with internal and external peers (Merchie et al., 2018). When teaching SEN-students it can be inspiring to teach these students with colleagues or observe each other's practices and give feedback. The third structural feature, 'school or site based', refers to the fact that the PDI is incorporated into the daily practices of members of the school team (Merchie et al., 2018). In order to understand and best meet the needs of school team members with regard to teaching SEN-students, the PDI needs to relate to their daily practices. In addition, professional development focussing on specific teachers' concerns and their teaching context are the most helpful and effective in encouraging change in teachers' practice (Kurniawati, de Boer, Minnaert, \& Mangunson, 2014). The fourth structural feature, 'active learning', requires that school team members 'are co-creators, rather than consumers of knowledge' (Merchie et al., 2018, p. 149). This means that school team members are actively involved in finding solutions for barriers that appear in their daily practices or the wider school environment. 'Trainer quality', the fifth structural feature, emphasizes the importance of alignment of the trainer's knowledge and skills with the needs and demands of the school team members (Merchie et al., 2018). For example, a trainer with a didactical background is preferred when a teacher needs to adjust his teaching approach in favour of a student with an autism spectrum disorder.

\subsection{This study}

Although the key features of PDIs, as displayed in the model of Merchie et al. (2018), have each been studied separately, no research has examined their joint effects. Moreover, they have not yet been applied to PDIs with regard to the realisation of IE, which is the focus of this study. Van Mieghem et al. (2020) concluded that teacher professionalization in favour of IE is of great importance with regard to the realization of a more IE system. After all, 
teachers play a crucial role with regard to implementing IE successfully and professional development of teachers is seen as a lever to achieve teacher confidence to teach SENstudents (Subban \& Sharma, 2005). However, little is known about how these PDIs affect the willingness of school team members to include SEN-students. Relying on these key features, we therefore set-up a comprehensive case study research and used the advanced method of 'qualitative comparative analysis (QCA)' to systematically analyse these key features of PDIs and how they jointly contribute to the willingness of school team members to include SENstudents in their school. The PDIs examined in this study are autonomously designed by various educational authorities, subsidized by the Flemish Department of Education after approval and aiming at enhancing teacher's competences to teach SEN-students. As a result of this autonomy, these PDIs differ from each other with regard to some key features of Merchie et al. (2018).

The following research questions will be addressed within this study:

RQ1. Which core features of PDIs, or combinations of these core features, are associated with the willingness of school team members to include SENstudents in their school?

RQ2. Which structural features of PDIs, or combinations of these structural features, are associated with the willingness of school team members to include SENstudents in their school?

In order to answer these research questions, a case study research was conducted, followed by a QCA to analyse the data systematically.

\section{Methodology}

\subsection{Case study research}

A multiple case study research design was chosen to get a deep understanding of how the implementation of the new IE legislation was conceived and implemented within schools. Case study research makes it possible to capture complex phenomena (Yin, 2014). This study is part of a larger research project, which took place in 20 purposefully sampled schools (10 primary, 10 secondary) in Flanders, based on a former participation in a PDI subsidized by the Flemish government and the last school inspectorate's feedback report, to ensure variation in the implementation stage of IE between cases (Rihoux \& Ragin, 2009). However, during one school visit to a primary school it appeared that the school team members had not 
previously participated in a PDI subsidized by the government, nor any other PDI in favour or IE. Consequently, this case school was not further taken into account for this study. In each school, informal observations were made, semi-structured interviews were conducted with members of the school leader team, and focus groups were held; one with teachers and one with internal and external counsellors, with on average approximately 4 participants in each focus group. Internal counsellors are employed by the school and coordinate and implement student guidance trajectories within the school in cooperation with teachers, the school leader, and parents. External counsellors are not employed by the school itself but are assigned to the school for a short or longer period to support students with more complex SEN and assist teachers and internal counsellors. The interviews were organised, during the period September - December 2017, two years after the new legislation (the M-decree) was voted. In total, 25 members of the school leader team, further referred to as school leaders, 73 teachers and 69 school counsellors participated in the study. During the interviews and focus groups, the perspectives of the respondents on their roles, perceptions, experienced difficulties, professionalization, and support were discussed. Data gathered from all 19 schools were systematically transcribed and analysed in two steps using content thematic analysis (Braun \& Clarke, 2006). First, a within-case analysis of each school was made in which the conditions and outcome variable per school were described. This was sent back as a member-check and approved by all school leaders. Secondly, a cross-case analysis was carried out using NVivo to score the key features of PDIs of Merchie et al. (2018) and the outcome variable (see below).

This research was approved by the Ethical Advisory Committee on Social Sciences and Humanities. In addition, all participants gave their consent to participate in the study. In order to ensure the anonymity of each case school, each primary case school was assigned a letter and the secondary case schools a numeral. Some additional background information on the case schools is provided in Table 1. 


\begin{tabular}{|c|c|c|c|c|c|}
\hline School & School network & $\begin{array}{l}\text { Urban } \\
\text { or } \\
\text { rural* }\end{array}$ & $\begin{array}{l}\text { School } \\
\text { size }^{* *}\end{array}$ & $\begin{array}{l}\text { SEN- } \\
\text { students*** }\end{array}$ & $\begin{array}{l}\text { Comprehensive } \\
\text { care policy } * * * *\end{array}$ \\
\hline A & Grant-aided free school & Rural & Small & Relatively low & Weak \\
\hline B & Grant-aided free school & Rural & Small & Relatively low & Intermediate \\
\hline $\mathrm{C}$ & Community school & Urban & Average & Relatively high & Strong \\
\hline $\mathrm{D}$ & Grant-aided free school & Urban & Large & Relatively high & Weak \\
\hline $\mathrm{E}$ & Community school & Rural & Average & Relatively low & Weak \\
\hline $\mathrm{F}$ & Grant-aided official school & Rural & Small & Relatively low & Intermediate \\
\hline $\mathrm{G}$ & Grant-aided free school & Rural & Large & Relatively low & Strong \\
\hline $\mathrm{H}$ & Grant-aided free school & Urban & Average & Relatively high & Weak \\
\hline $\mathrm{I}$ & Grant-aided free school & Rural & Small & Relatively low & Intermediate \\
\hline $\mathrm{J}$ & Grant-aided free school & Rural & Large & Relatively low & Strong \\
\hline 1 & Grant-aided official school & Urban & Small & Relatively high & Weak \\
\hline 2 & Community school & Rural & Small & Relatively high & Intermediate \\
\hline 3 & Grant-aided free school & Urban & Average & Relatively low & Strong \\
\hline 4 & Grant-aided official school & Urban & Large & Relatively high & Intermediate \\
\hline 5 & Grant-aided official school & Urban & Average & Relatively high & Weak \\
\hline 6 & Community school & Urban & Average & Relatively high & Intermediate \\
\hline 7 & Grant-aided official school & Rural & Small & Relatively high & Strong \\
\hline 8 & Grant-aided free school & Rural & Average & Relatively low & Weak \\
\hline 9 & Grant-aided free school & Urban & Large & Relatively high & Intermediate \\
\hline 10 & Grant-aided free school & Rural & Large & Relatively low & Strong \\
\hline \multicolumn{6}{|c|}{$\begin{array}{l}\text { *rural located school: } 6000 \leq 27000 \text { inhabitants; urban located school: } 27000 \leq 500000 \text { inhabitants; based on } \\
\text { statistics of the Belgian Federal Public Service Home Affairs }(2017) ; \\
\text { ** primary schools: small school } \leq 200 \text { students, average school } 200>\text { students } \leq 500 \text {, large school }>500 \\
\text { students; secondary schools: small school } \leq 500 \text { students, average school } 500>\text { students } \leq 800 \text {, large school }> \\
800 \text { students; } \\
\text { ***relatively low = rather few SEN-students; relatively high = rather more SEN-students; based on observations } \\
\text { made by the researchers at the school and the examples of SEN-students given by teachers and counsellors } \\
\text { within the focus groups and numbers received by the school leaders; } \\
* * * * \text { weak = a care policy is weakly outlined; intermediate = a care policy is outlined but can be improved; } \\
\text { strong = a comprehensive care policy is outlined; based on the most recent school inspectorate's feedback } \\
\text { report. }\end{array}$} \\
\hline
\end{tabular}

\subsection{Qualitative comparative analysis (QCA)}

We opted for QCA as an analysis method to investigate the key features of PDIs that are related to the willingness of school team members to include SEN-students (Rihoux \& Ragin, 2009). To date, QCA has mainly been applied in case study research in political sciences and its use in educational research is scarce. Therefore, a brief description of the method is provided here. QCA is a case-based, qualitative, comparative analysis method that combines the in-depth insight of case studies with the inferential power of 'large- $\mathrm{N}$ ' studies. Consequently, QCA allows the generalization of findings from a relatively small number of cases and offers the ability to identify conditions, or combinations thereof, that are associated with a similar outcome (Ragin, 1987). Furthermore, QCA can be used in multiple ways, from 
'summarizing data' to 'checking hypotheses or existing theories' (Rihoux \& Ragin, 2009). The latter enables researchers to corroborate or falsify hypotheses. Rihoux and Ragin (2009) consider QCA as a 'powerful tool for this kind of application because it allows hypothesis testing that is both systematic and empirical.' (p.16). In order to do so, a hypothesis must be operationalized by a series of conditions and a particular outcome.

The number of conditions that can be included within QCA analysis depends on the number of cases that is being studied (Marx, Cambré, \& Rihoux, 2013). Additionally, an outcome variable needs to be defined. Defining the conditions and outcome is an iterative process that is influenced by literature and the cases involved in the study (Rihoux \& Ragin, 2009).

Further, QCA aims to address necessary (has to be present for the outcome to occur) and sufficient conditions (can produce the outcome by itself), or combinations thereof, which are associated with the outcome of interest. Moreover, QCA includes all theoretically possible combinations of conditions, called logical remainders, in order to obtain the most parsimonious minimal formula that is associated with the outcome of interest (Rihoux \& Ragin, 2009). However, a minimal formula can only be obtained if no contradictory configurations occur. Within a contradictory configuration cases with similar conditions, but with and without the outcome of interest are observed. These contradictory configurations can be resolved in multiple ways, such as adding or deleting conditions, re-examining the conditions and/or outcome variable, or re-examining the cases involved in the contradictory configurations. If none of these strategies can resolve these contradictory configurations and it is used for testing a hypothesis, then you are allowed to falsify it (Ragin \& Rihoux, 2009). Consequently, QCA requires the researcher to identify conditions (step 1) within each case that can be associated with a certain outcome of interest (step 2) (Rihoux \& Ragin, 2009). A crisp-set QCA (csQCA) analysis is preferred when analysing 19 cases (Rihoux and Ragin, 2009), which implies that each condition and the outcome will get a score of 0 (fully out) or 1 (fully in) for each school case.

\section{Step 1: Defining and calibrating conditions}

The four core features and the five structural features of PDIs of Merchie et al. (2018) are treated as separate sets of conditions in two QCA's. When analysing four or five conditions, at least 12 or 17 cases need to be included in the study (Marx, Cambré, and Rihoux, 2013). In line with the QCA literature, a rubric was developed (Table 2), based on literature and the 
cases, to assign codes ( 0 or 1$)$ to the conditions for each case school (Rihoux \& Ragin, 2009).

Each condition was scored based on the answers of the school leaders.

\begin{tabular}{|c|c|}
\hline \multicolumn{2}{|c|}{$\begin{array}{l}\text { Table 2. Coding rubric developed to score key features of PDIs as conditions in each } \\
\text { case school }\end{array}$} \\
\hline Conditions & A score of 1 is given when: \\
\hline \multicolumn{2}{|l|}{ Core features } \\
\hline (1) Content focus & The focus of the PDI was on the learning or teaching of student(s) with SEN. \\
\hline (2) Pedagogical knowledge & $\begin{array}{l}\text { The main focus of the PDI was to purposefully develop teachers' knowledge and } \\
\text { skills to teach SEN-students. }\end{array}$ \\
\hline (3) Coherent and evidence-based & The content of the PDI was in line with the learning objectives of the school team. \\
\hline (4) Ownership & The school team experiences ownership with regard to the PDI. \\
\hline \multicolumn{2}{|l|}{ Structural features } \\
\hline (1) Duration & The PDI amounted at least 20 hours contact time. \\
\hline $\begin{array}{l}\text { (2) Collective or collaborative } \\
\text { participation }\end{array}$ & $\begin{array}{l}\text { The PDI consisted mainly of a collaboration between the school team and the } \\
\text { organizers of the PDI. }\end{array}$ \\
\hline (3) School- or site based & The PDI was mainly based on the daily practices of members of the school team. \\
\hline (4) Active learning & Members of the school team were mainly actively involved during the PDI. \\
\hline (5) Trainer quality & The knowledge and skills of the organizer(s) of the PDI are valued as high. \\
\hline
\end{tabular}

\section{Step 2: Defining and calibrating the outcome of interest}

The outcome of interest for this study is whether school team members are willing to include SEN-students within their school. To investigate this, a vignette method was used with all focus groups (teachers and school counsellors). Each respondent of each focus group was given three hypothetical but realistic vignettes of students with different SEN (behavioural problems, learning difficulties, and intellectual disability, see Figure 2) and was asked to answer whether these students would be enrolled in the school and how they would feel about that decision. The choice of these vignettes was based on previous research showing that teachers, parents and typically developing students are less positive towards students with behavioural problems, learning disabilities and severe cognitive impairment compared with students with physical disabilities and sensory impairments (Avramidis \& Norwich, 2002; de Boer et al., 2011). 


\begin{tabular}{||l}
\hline \hline Vignette 1 Emre can hardly control his feelings and exhibits challenging behaviour. Any small \\
incident can make him very angry. During such a temper tantrum, he already hit another \\
child and gave him a black eye. On the recommendation of his previous school, he is \\
following therapy for students with behavioural control difficulties. Thanks to the \\
therapy, his behaviour has improved. In the previous school year, his family moved to \\
the neighbourhood where your school is located. He would like to attend classes at your \\
school. \\
\hline Vignette 2 As a toddler, Sarah showed delayed development. It took a long time for her to walk \\
and talk. Previously, the school's counselling team considered the option of \\
transitioning to special education because of Sarah's learning backlog. Sarah has been \\
retained for one year. She shows very little school progress, as well as symptoms of low \\
intellectual ability, but this has never been tested. Sarah's brother and sister attend \\
classes at your school. Sarah's parents would prefer Sarah to stay with her brother and \\
sister. They want to keep her in this school. \\
Max has been diagnosed as having an intellectual impairment. He went to regular \\
kindergarten, but from the first grade on, he went to a school for special education. Here \\
he received intensive support to master subject matter sufficiently. He was taught in \\
small class groups. Max has to spend two hours on the school bus to get to the school. \\
Therefore, he has to wake up at a quarter to six every day because the school bus picks \\
him up a quarter after six. Thanks to the intensive guidance, Max has improved \\
significantly. He has a school delay of one year. For Dutch and mathematics he lags two \\
years behind and he has never been taught a second language (i.e. French). This year he \\
would like to follow classes in your school, which is located around the corner from his \\
house. After school hours, he will be further guided by specialists who support him in \\
his school work.
\end{tabular}

Figure 2. Vignettes of SEN-students used for teachers and counsellors

The answers of all teachers and counsellors in each focus group were added together per vignette. Consequently, the enrolment choices of the two focus groups for the three fictitious SEN-students (i.e., 6 student cases in total) were examined per case school. A case school was coded with 1 when five or six students would be enrolled, or if four students would be enrolled and there is doubt about two students. A case school was coded with 0 if at least two students would not be enrolled within the school, or if one student would not be enrolled and there is doubt about another student, or if there is doubt about three students. It should be kept in mind when reading this calibration method that SEN-students have the right to enrol in a regular school in Flanders.

To assess interrater agreement, the outcome variable of each case school was coded independently by a second coder. An $80 \%$ interrater agreement was found, corresponding to a kappa coefficient of .61, which indicates a substantial strength of agreement (Landis \& Koch, 1977). 


\section{Results}

In order to answer the research questions, we analysed how case schools scored on the key features of PDIs as described by Merchie and colleagues (2018) and on the outcome variable of interest, namely 'willingness to include students with SEN', which can be seen as the intention to perform a given behaviour (Ajzen, 1991). Next, we examined how these core and structural features were related to school team members' willingness to include SENstudents.

\subsection{Combining key features and the willingness into configurations}

All codes given for each core and structural key features and the outcome variable for every case school, called configurations, are included in Table 3 and 4, which are called Truth tables. If more than one case school had the same configuration, than these case schools were put together (see e.g., Table 3: 9, 10). In addition, the configurations were ranked according to their outcome: first, all configurations with a [0] outcome; second, all configurations with a [1] outcome; third, contradictory configurations [C] are mentioned. Within a contradictory configuration cases with a [0] outcome as well as a [1] outcome are observed.

Table 3. Truth table of core features of PDI and outcome for willingness to include SENstudents

\begin{tabular}{lccccc}
\hline School* & $\begin{array}{l}\text { (1) content } \\
\text { focus }\end{array}$ & $\begin{array}{l}\text { (2) pedagogical } \\
\text { knowledge }\end{array}$ & $\begin{array}{l}\text { (3) coherent } \\
\text { and evidence- } \\
\text { based }\end{array}$ & $\begin{array}{l}\text { (4) } \\
\text { ownership }\end{array}$ & $\begin{array}{l}\text { Outcome**: } \\
\text { Willingness } \\
\text { to include } \\
\text { SEN- } \\
\text { students }\end{array}$ \\
\hline $\mathrm{A}$ & 0 & 1 & 0 & 0 & 0 \\
\hline 9,10 & 0 & 0 & 1 & 0 & 0 \\
\hline 5 & 1 & 0 & 0 & 1 & 0 \\
\hline $\mathrm{F}$ & 0 & 1 & 0 & 1 & 0 \\
\hline $\mathbf{4}$ & 1 & 1 & 0 & 0 & 1 \\
\hline $\mathbf{C}, 3, \mathrm{G}$ & 0 & 0 & 0 & 0 & $\mathrm{C}$ \\
\hline $\mathbf{I}, \mathbf{1}, \mathbf{H}, \mathbf{6}, \mathbf{7}, \mathrm{D}, 8$ & 0 & 0 & 1 & 1 & $\mathrm{C}$ \\
\hline
\end{tabular}

*Schools presented in bold have outcome [1], not in bold have outcome [0]; **C=Contradictory configurations

Table 4. Truth table of structural features of PDI and outcome for willingness to 


\begin{tabular}{llllllc}
\hline include SEN-students & & & & & \\
\hline School* & $\begin{array}{l}\text { (1) } \\
\text { duration }\end{array}$ & $\begin{array}{l}\text { (2) collective } \\
\text { or } \\
\text { collaborative } \\
\text { participation }\end{array}$ & $\begin{array}{l}\text { (3) school- } \\
\text { or site } \\
\text { based }\end{array}$ & $\begin{array}{l}\text { (4) active } \\
\text { learning }\end{array}$ & $\begin{array}{l}\text { (5) } \\
\text { trainer } \\
\text { quality }\end{array}$ & $\begin{array}{l}\text { Outcome**: } \\
\text { Willingness } \\
\text { to include } \\
\text { SEN- } \\
\text { students }\end{array}$ \\
\hline 3 & 1 & 1 & 0 & 0 & 0 & 0 \\
\hline 10 & 0 & 1 & 0 & 0 & 1 & 0 \\
\hline 9 & 0 & 0 & 1 & 0 & 1 & 0 \\
\hline 5 & 0 & 1 & 1 & 1 & 0 & 0 \\
\hline 8 & 0 & 1 & 1 & 0 & 1 & 0 \\
\hline F, G & 1 & 1 & 1 & 1 & 0 & 0 \\
\hline $\mathbf{7}$ & 0 & 0 & 0 & 1 & 1 & 1 \\
\hline $\mathbf{C , 4}, \mathrm{A}$ & 1 & 0 & 0 & 0 & 0 & $\mathrm{C}$ \\
\hline $\mathbf{1 , 2}$ & 1 & 1 & 0 & 1 & 1 & $\mathrm{C}$ \\
\hline $\mathbf{B}, \mathbf{I}, \mathrm{H}$ & 0 & 1 & 1 & 1 & 1 & $\mathrm{C}$ \\
\hline $\mathbf{E}, \mathbf{6}, \mathrm{D}$ & 1 & 1 & 1 & 1 & 1 & $\mathrm{C}$ \\
\hline
\end{tabular}

*Schools presented in bold have outcome [1], not in bold have outcome [0]; ** $\mathrm{C}=$ Contradictory configurations

A systematic analysis of the relationship between the core and structural features and the outcome, based on the truth tables, is discussed below.

\subsection{Relating core and structural features to the willingness to include SEN-students}

After compiling the truth tables, csQCA's were performed using the TOSMANA software (Cronqvist, 2018).

The csQCA's in TOSMANA (Cronqvist, 2018) revealed no pathway or minimal formula of (combinations of) core features or structural features of PDIs, nor a separate feature that could be identified as a necessary or sufficient condition in relation to the willingness to include SEN-students. Consequently, the researchers conclude that none of the core or structural features, nor a combination of these core or structural features, are associated directly with the willingness of school team members to include SEN-students within their school. Moreover, the truth table of core features (Table 3) reports three contradictory configurations, representing 13 case schools $(\mathbf{C}, 3, \mathrm{G}+\mathbf{I}, \mathbf{1}, \mathrm{H}, 2+\mathbf{B}, \mathbf{E}, \mathbf{6}, \mathbf{7}, \mathrm{D}, 8)$ and the truth table of structural features (Table 4) reports four contradictory configurations, representing 11 case schools $(\mathbf{C}, \mathbf{4}, \mathrm{A}+\mathbf{1}, 2+\mathbf{B}, \mathbf{I}, \mathrm{H}+\mathbf{E}, \mathbf{6}, \mathrm{D})$. When contradictory configurations occur, csQCA demands the researcher to resolve these contradictions, for example through adding or deleting conditions, reconsidering the obtained conditions and outcome, and re-examine the cases in the contradictory configurations, which the researchers did (Rihoux \& Ragin, 2009). As none of these strategies were helpful, we concluded that 
csQCA has allowed us to falsify the theory (Rihoux \& Ragin, 2009). In addition, when reexamining the involved cases in the contradictory configurations, two possible explanations were obtained, which are further elaborated below.

\subsection{Explanations for not finding an association between PDI-features and the willingness to include SEN-students}

Two hypotheses emerged for not finding a pathway or minimal formula within the core or structural features of PDIs in relation to willingness to include SEN-students. First, the researchers found indications that (positive) experiences with SEN-students are more decisive for the willingness of school team members to include SEN-students than the PDI features. Second, the content of most of these PDIs was rather specific (see Table 2; Core features: Content focus). Both hypotheses are further explained below. The first hypothesis is illustrated with regard to three case schools that are part of the contradictory configurations with an unexpected outcome in relation to the core features of PDIs.

\section{Case school D and 8}

All core features of the PDIs of case school D and 8 were rated with one, from which it can be derived that these PDIs were positively assessed by these school teams. Nevertheless, the outcome was rated with [0] for these case schools. School team members of school D reported multiple negative experiences with SEN-students. These negative experiences resulted in low confidence of the school team members to teach SEN-students and thus they were convinced that these students could better be enrolled in special education. Consequently, the willingness to include SEN-students was low.

I do not believe that this [IE] can be achieved within general education. That is a very nice idea, I would like that for every child as well, but I think that some children would be better-off in special education, where they are able to develop at their level, in a small group, a familiar environment. (Teachers, D)

Also, within case school 8, a rural school that attracts more high achieving students and thus has less experience with SEN-students, school team members were convinced that SENstudents could be better supported within special education. 


\section{Case school C}

Case school $\mathrm{C}$ has rated all core features with zero, which indicates that the PDI was not received positively by the school team. Nonetheless, willingness to include SEN-students was found in this school. The researchers noticed that case school C has multiple SEN-students and consequently a lot of experience with SEN-students. Furthermore, case school $\mathrm{C}$ has already developed a well thought out care policy (see Table 1) and adapted its daily practices in line with this policy. In addition, the PDI did not meet the more complex needs of case school C's teachers. Nevertheless, the PDI did not seem to affect the willingness of these school team members to include SEN-students in a negative way.

We actually concluded that we are doing well. It [the PDI] confirmed what we already knew: ok, we do have a well-developed care system and care policy [...]. So yes, it was actually a good moment for reflection with various parties, but it didn't really surprise us. (School leader, C)

Second, the content of most of these PDIs was rather specific; related to specific needs of SEN-students (see 3.1.1. Core features: Content focus). However, the needs of individual SEN-students vary, as well as improving and adapting classroom practices to these needs, which makes it an ongoing process. Consequently, school team members, especially teachers, experience different needs to teach students with different SEN, which are addressed in different PDIs. Therefore, it is hypothesized that a PDI can be a lever for the participants to include students with specific SEN, however, multiple PDIs will be needed to obtain willingness to include a variety of students with different SEN.

That is the uniqueness of the M-decree, every student who is enrolled within the school with a specific care or support need [...] has a unique question. These unique questions, demand specific answers. [...] It is a search we must complete with that student, the parents and involved teachers as well. That is why I also think: it is a never ending process. (School leader, 7)

\section{Discussion and conclusion}

The goal of this study was to get a deeper insight in how professional development initiatives (PDIs) aimed at supporting IE are associated with the willingness to include students with special educational needs (SEN) in mainstream schools. To describe differences 
in PDIs, we used the component of the framework of Merchie and colleagues (2018) that distinguishes core and structural features.

With regard to the four core features: (1) content focus, (2) pedagogical knowledge, (3) coherent and evidence-based, and (4) ownership, it was found that the absence or presence of these features, or a combination thereof, could not be associated with the willingness of school team members to include SEN-students.

Also, the absence or presence of the five structural features: (1) duration, (2) collective or collaborative participation, (3) school or site based, (4) active learning, and (5) trainer quality, or a combination thereof, could not be associated with the willingness in general of school team members to include SEN-students.

Moreover, after studying contradictory configurations in more detail, the results indicated that positive experiences with SEN-students have more impact on the willingness to include SEN-students than the PDI features. Furthermore, it seems that other aspects of the evaluative framework for mapping the effects of PDIs of Merchie and colleagues (2018) can be a lever to create more willingness to include students with similar SEN in the future. However, multiple PDIs focussing on different SEN related to specific students are needed obtain willingness to include a variety of students with different SEN.

The willingness of school team members to include SEN-students seems to be strongly related to their experiences with these students, which is also echoed within the literature (e.g., Avramidis \& Kalyva, 2007). If these experiences are successful, then more willingness to include SEN-students was found. This finding can be related to the self-efficacy theory of Bandura (1997). Self-efficacy refers to a person's beliefs in his capabilities to execute a certain task (Bandura, 1997), which is also an element within the extensive framework of Merchie et al. (2018) ('affective goals': teachers beliefs about themselves, see Appendix). Bandura (1997) mentions four sources for shaping self-efficacy beliefs: (1) enactive mastery experience, prior experiences with the tasks; (2) vicarious experience, performances of similar others' on the tasks; (3) verbal persuasion, feedback from significant others; and (4) physiological reactions, physiological arousals (e.g. heartbeats) and emotional reactions. In line with our findings, 'enactive mastery experience' is considered to be the strongest source of self-efficacy (e.g., Malinen et al., 2013). In addition, previous research has demonstrated that teachers with high self-efficacy beliefs are more likely to adjust and improve daily practices in favour of SEN-students (e.g., Caprara, Barbaranelli, Steca, \& Malone, 2006). Therefore, positive experiences with SEN-students should accompany the PDI. In addition, 
all sources of Bandura (1997) could be taken into account when designing PDIs, for example by also using role models who have positive experiences with SEN-students, giving feedback, and addressing negative emotions. Within the extensive framework of Merchie et al. (2018) teacher appraisal and feedback is part of the 'contextual factors: micro-context' (see Appendix).

Furthermore, it seems that a PDI can enhance the willingness of school team members to include students with specific SEN. It was found that the content of most PDIs focused on specific needs related to SEN-students. This is in line with previous research that states that PDIs in favour of IE should focus on specific student needs or disabilities, specific teachers' concerns, and their teaching context (e.g., Kurniawati et al., 2014; Van Mieghem et al., 2020). However, different specific needs are related to teaching students with different SEN. Consequently, adapting and improving daily practices is an ongoing process, to which teachers experience different needs in relation to the SEN-students they teach. Ainscow (2005) confirms that inclusion is a never-ending search of finding better ways to respond to the needs of the learner. Therefore, the researchers hypothesize that multiple PDIs with a content focus on different SEN need to be provided, so that teachers can participate in the PDI that meets their needs.

In line with these findings and hypotheses, we can infer that willingness in general to include SEN-students can not be predicted by the core or structural features, or a combination of these core or structural features, as outlined within the extensive framework of Merchie and colleagues (2018) (see Appendix). However, self-efficacy beliefs of school team members, based on prior experiences with SEN-students, seem to relate to their willingness. Self-efficacy beliefs of teachers are also part of the framework of Merchie et al. (2018) (see Appendix, teacher quality: affective goals). Furthermore, teacher appraisal and positive feedback (see Appendix, contextual factors: micro-context in Merchie et al., 2018) related to teaching SEN-students, can enhance teachers' self-efficacy beliefs. Therefore, we conclude that it is more complex to predict the willingness of school team members to include SENstudents, and that other aspects, such as self-efficacy beliefs and the sample size, need to be taken into account.

The willingness of school team members to include SEN-students seems to depend on prior experiences with these students. Because these behavioural intentions are rather firm, positive 
experiences with SEN-students should accompany the PDI. Furthermore, indications were found that PDIs can enhance the willingness of school team members to include students with specific SEN. Consequently, multiple PDIs focussing on different SEN related to specific students are needed to create willingness to include students with a variety of SEN.

Finally, some strengths and limitations of this study are acknowledged. A strength of this study is that a relative new analysis technique within educational research, QCA, is used to systematically examine case studies in order to obtain new hypotheses with regard to conditions related to realizing a more inclusive school system. This study particularly focuses on (the combination of) key features of PDIs in relation to the willingness of school team members to include SEN-students. Furthermore, a comprehensive case study research was set up in which school leaders, teachers and counsellors were interviewed in several case schools $(\mathrm{N}=20)$ allowing us to get a deeper insight in the implementation process of IE in Flanders. A limitation of this study is that the outcome variable - the willingness to enrol a student with SEN - does not necessarily mean that these students are effectively enrolled within the schools; but is acknowledged as a first step to achieve IE. The vignette method allows us to get an indication in each case school whether or not the same fictive student will be enrolled, which makes it possible to compare case schools with regard to their willingness to include SEN-students. Furthermore, within this study, we used one framework of PDIs, the extensive framework of Merchie et al. (2018). However, future research could include other features of professional development, for example aspects of learning communities as described by Walton, Carrington, Saggers, Edwards, and Kimani (2019). They concluded that if and when learning communities (of whatever variety) emerge or are created to support professional learning for inclusive teaching, there are three factors which can be seen as necessary, though perhaps not sufficient, for their functioning: responsiveness to contextual exigencies, expertise and supportive networks' (p. 13). Additionally, the data collection took place at one point in time. At that point, the new legislation was only implemented for two years. In addition, the conclusion of this research strengthens the importance of more extensive research on the impact of positive and negative experiences of school team members with SEN-students and how these experiences can be influenced by PDIs. 


\section{Funding details}

This study was supported by The Research Centre 'Educational research' (SONO) and was funded by the Flemish Government.

\section{Disclosure statement}

No potential conflict of interest was reported by the authors.

\section{Biographical note}

Aster Van Mieghem, MSc, is currently working on her $\mathrm{PhD}$ thesis on the perceptions of practitioners on the implementation of inclusive education in Flanders. She is affiliated with the Department of Training and Education Sciences in the Faculty of Social Sciences, University of Antwerp, and the Research Unit School of Psychology and Development in Context of the KU Leuven, Belgium.

Karine Verschueren, $\mathrm{PhD}$, is full professor in Psychology and coordinator of the Research Unit School of Psychology and Development in Context, Faculty of Psychology and Educational Sciences, at the KU Leuven, Leuven. She conducts research on the psychosocial and academic development of students and the role of teacher-student and peer relationships, both in the general student populations and in specific groups (e.g., socially disadvantaged students, high ability students).

Elke Struyf, $\mathrm{PhD}$, is full professor in Education Sciences. Within the research group EduBROn, Faculty of Social Sciences at the University of Antwerp, she conducts research on teachers' expertise development, its relationship with characteristics in the contextual (classroom or school) environment, and students' outcomes. 
Appendix. Adjusted extended evaluative framework for mapping the effects of PDIs (Merchie et al., 2018)

\begin{tabular}{|c|c|c|c|}
\hline $\begin{array}{l}\text { FEATURES OF THE } \\
\text { INTERVENTION } \\
\text { Core features } \\
-\quad \text { content focus } \\
\text { - } \quad \text { pedagogical } \\
\text { knowledge } \\
\text { - } \quad \text { coherent and } \\
\text { - } \quad \text { vidence-based } \\
\text { ownership } \\
\text { Structural features } \\
-\quad \text { duration } \\
-\quad \text { collective or } \\
\text { collaborative } \\
\text { - } \quad \text { participation } \\
\text { - } \quad \text { active learning } \\
\text { - } \quad \text { trainer quality }\end{array}$ & $\begin{array}{l}\text { TEACHER QUALITY } \\
\text { Cognitive goals } \\
\text { (knowledge) } \\
\text { - pedagogical } \\
\text { knowledge (PK) } \\
\text { pedagogical } \\
\text { content knowledge } \\
\text { (PCK): } \\
\text { students/teaching } \\
\text { Skills } \\
\text { Affective goals } \\
\text { (attitudes/beliefs) } \\
\text { teachers beliefs } \\
\text { about learning and } \\
\text { teaching } \\
\text { teachers beliefs } \\
\text { about themselves }\end{array}$ & $\begin{array}{l}\text { TEACHING } \\
\text { BEHAVIOR } \\
\text { Instructional strategies/ } \\
\text { practices } \\
\text { Interaction patterns } \\
\text { - teachers-students } \\
\text { - } \quad \text { among teachers } \\
\text { - } \quad \text { among students }\end{array}$ & $\begin{array}{l}\text { Domain-specific } \\
\text { knowledge and skills } \\
-\quad \text { mathematics } \\
-\quad \text { science } \\
-\quad \text { literacy/language } \\
-\quad \text { history } \\
\text { Domain general } \\
\text { knowledge and skills } \\
-\quad \text { socio-emotional } \\
-\quad \text { self-regulated } \\
\quad \text { learning }\end{array}$ \\
\hline
\end{tabular}

\section{Contextual factors}

macro-societal conditions: policy environment, curriculum/standards

micro-context: administration, organization (school management practices), school leadership and support, resources, socioeconomic status, teacher appraisal and feedback, school autonomy, professional community

\section{Teachers' personal characteristics}

$$
\begin{aligned}
& \text { gender } \\
& \text { age } \\
& \text { qualification level }
\end{aligned}
$$

Student's personal characteristics self-concept 


\section{References}

Ainscow, M. (2005). Developing inclusive education systems: what are the levers for change? Journal of educational change, 6(2), 109-124.

Ainscow, M., Booth, T., \& Dyson, A. (2006). Improving Schools, Developing Inclusion. Abingdon: Routledge.

Ajzen, I. (1991). The theory of planned behavior. Organizational behavior and human decision processes, 50(2), 179-211.

Avramidis, E., \& Kalyva, E. (2007). The influence of teaching experience and professional development on Greek teachers' attitudes towards inclusion. European Journal of Special Needs Education, 22(4), 367-389. Doi:10.1080/08856250701649989.

Avramidis, E., \& Norwich, B. (2002). Teachers' attitudes towards integration/inclusion: a review of the literature. European Journal of Special Needs Education, 17(2), 129-147. Doi:10.1080/08856250210129056.

Bandura, A. (1997). Self-efficacy: The exercise of control. New York, NY: W.H. Freeman.

Booth, T., \& Ainscow, M. (2002). The index for inclusion. Bristol: Centre for Studies in Inclusive Education.

Borko, H. (2004). Professional Development and Teacher Learning: Mapping the Terrain. Educational Researcher, 33(8), 3-15. Doi:10.3102/0013189X033008003.

Braun, V., \& Clarke, V. (2006). Using thematic analysis in psychology. Qualitative research in psychology, 3(2), 77-101. Doi:10.1191/1478088706qp063oa.

Caprara, G. V., Barbaranelli, C., Steca, P., \& Malone, P. S. (2006). Teachers' self-efficacy beliefs as determinants of job satisfaction and students' academic achievement: A study at the school level. Journal of school psychology,44(6), 473-490. Doi:10.1016/j.jsp.2006.09.001.

Children's Rights Commissioner (2016). Knelpuntennota M-decreet. [Barriers M-decree]. Accessed August 6 , 2019. https://www.kinderrechtencommissariaat.be/sites/default/files/bestanden/2015_2016_11_k nelpuntennota_m-decreet_31_mei_2016.pdf

Cronqvist, L. (2018). Tosmana [Version 1.6]. University of Trier. Internet: https://www.tosmana.net.

de Boer, A., Pijl S. J., \& Minnaert, A. (2011). Regular primary schoolteachers' attitudes towards inclusive education: a review of the literature. International Journal of Inclusive Education, 15(3), 331-353. Doi:10.1080/13603110903030089. 
Desimone, L. M. (2009). Improving Impact Studies of Teachers' Professional Development: Toward Better Conceptualizations and Measures. Educational Researcher, 38(3), 181199. Doi:10.3102/0013189X08331140.

Fixsen, D., Blase, K., Metz, A., \& Van Dyke, M. (2013). Statewide implementation of evidence-based programs. Exceptional Children, 79(2), 213-230.

Flemish Ministry of Education and Training (2014). M-Decreet [Measures for Children with $\begin{array}{llllll}\text { Special } & \text { Educational Needs]. Accessed } & \text { April 17, }\end{array}$ http://onderwijs.vlaanderen.be/nl/het-abc-van-hetm-decreet-maatregelen-specifiekeonderwijsbehoeften.

Kurniawati, F., de Boer, A. A., Minnaert, A. E. M. G., \& Mangunsong, F. (2014). Characteristics of primary teacher training programmes on inclusion: a literature focus. Educational Research, 56(3), 310-326. Doi:10.1080/00131881.2014.934555.

Landis, J. R., \& Koch, G. G. (1977). The measurement of observer agreement for categorical data. Biometrics, 33(1), 159-174.

Malinen, O. P., Savolainen, H., Engelbrecht, P., Xu, J., Nel, M., Nel, N., \& Tlale, D. (2013). Exploring teacher self-efficacy for inclusive practices in three diverse countries. Teaching and Teacher Education, 33, 34-44. Doi:10.1016/j.tate.2013.02.004.

Marx, A., Cambré, B., \& Rihoux, B. (2013). Chapter 2 crisp-set qualitative comparative analysis in organizational studies. In P. Fiss, B. Cambré, and A. Marx, (Eds.) Configurational theory and methods in organizational research (pp. 23-47). Emerald Group Publishing Limited.

Merchie, E., Tuytens, M., Devos, G., \& Vanderlinde, R. (2018). Evaluating teachers' professional development initiatives: towards an extended evaluative framework. Research papers in education, 33(2), 143-168. Doi:10.1080/02671522.2016.1271003.

Pijl, S. J., \& Frissen, P. H. A. (2009). What policymakers can do to make education inclusive. Educational Management Administration \& leadership, 37(3), 366-377. Doi:10.1177/1741143209102789.

Rihoux, B., \& Ragin, C. (2009). Configurational Comparative Methods: Qualitative Comparative Analysis (QCA) and related techniques. SAGE: Los Angeles, London, New Delhi, Singapore.

School inspectorate (2018). Onderzoek Leerlingenbegeleiding. Hoe kwaliteitsvol is de leerlingenbegeleiding in de basisscholen en in de eerste graad secundair onderwijs? [Student guidance research. How is the quality of student counseling in primary schools and in the first stage of secondary education?]. Accessed August 6, 2019. 
https://www.onderwijsinspectie.be/sites/default/files/atoms/files/Onderzoeksrapport\%20L eerlingenbegeleiding\%20\%28januari\%202018\%29_0.pdf

Struyf, E., Verschueren, K, Petry, K, \& Van Mieghem, A. (2018). Dynamieken achter de implementatie van het M-decreet: Een casestudieonderzoek. [Dynamics behind the implementation of the M-decree: A case study.] Steunpunt Onderwijsonderzoek, Gent.

Subban, P., \& Sharma, U. (2005). Understanding educator attitudes toward the implementation of inclusive education. Disability Studies Quarterly, 25(2).

United Nations (2006). Convention on the Rights of Persons with Disabilities and Optional Protocol. Resolution Adopted by the General Assembly. Accessed May 16, 2018. http://www.un.org/disabilities/documents/convention/convoptprot-e.pdf.

Van Mieghem, A., Verschueren, K., Petry, K., \& Struyf, E. (2020). An analysis of research on inclusive education: a systematic search and meta review. International Journal of Inclusive Education, 24(6), 675-689.

Vansteenkiste, D., Swart, E., Van Avermaet, P., \& Struyf, E. (2020). Professional Development for Inclusive Education? In U. Sharma \& S. J. Salend (Eds.), Oxford Encyclopedia on Inclusive and Special Education. New York: Oxford University Press.

Walton, E., Carrington, S., Saggers, B., Edwards, C., \& Kimani, W. (2019). What matters in learning communities for inclusive education: a cross-case analysis. Professional Development in Education, 1-15. Doi:10.1080/19415257.2019.1689525.

Yin, R. K. (2014). Case study research: Design and methods (Fifth). London: SAGE. 